KOŚCIÓŁ I PRAWO 10(23) 2021, nr 1, s. 195-226

DOI: http://dx.doi.org/10.18290/kip21101-11

Paweł Nowik

\title{
FORMACJA INTELEKTUALNA \\ KS. STEFANA WYSZYŃSKIEGO \\ W DZIEDZINIE PRACY LUDZKIEJ I USTAWODAWSTWA PRACY - OKRESY II RP I II WOJNY ŚWIATOWEJ
}

\section{WPROWADZENIE}

Ksiądz Wyszyński zaliczany jest do grona polskich współtwórców katolickiej nauki społecznej. W gronie prekursorów tej nowej dziedziny wiedzy nie odgrywał roli pierwszoplanowej, jak Jego mistrz ks. Antoni Szymański, był jednak ceniony przez ówczesne kręgi intelektualne i kościelne. Ks. Wyszyński katolicką naukę społeczną rozumiał jako dziedzinę wiedzy, której przewodnią ideą jest „powiązanie wartości przyrodzonych życia gospodarczego, dobra materialne $\mathrm{z}$ wartościami moralnymi i nadprzyrodzonymi” [Wyszyński 2020, 22]. Nie utożsamiał jej wyłącznie z katolicką etyką gospodarczą, a raczej rozumiał jako nowy rodzaj wiedzy, która „wyprowadza syntezę nową, odrębną od wartościowania samej etyki i samej ekonomiki” [tamże]. Jak wyjaśniał, „z tej syntezy powstanie nowe wartościowanie już nie tylko pod kątem ich przyrodzonych przeznaczeń, ale pod kątem ostatecznych racji bytu tych wartości i bytu oraz działania człowieka" [tamże]. Tego typu integralne myślenie dotyczy także zagadnienia pracy człowieka, które w opinii ks. Wyszyńskiego powinno być rozpatrywane jako

DR HAB. PAWEŁ NowIK - Katedra Prawa Pracy i Ubezpieczeń Społecznych, Wydział Prawa, Prawa Kanonicznego i Administracji, Katolicki Uniwersytet Lubelski Jana Pawła II; adres do korespondencji: Al. Racławickie 14, 20-950 Lublin, Polska; e-mail: pawelnowik@kul.pl; https://orcid.org/0000-0002-1824-0884 
synteza świeckiej nauki społecznej z nauką kościelną [Bartnik 2001, 8]. W swoim ważnym dziele, książce „Duch pracy ludzkiej. Myśli o wartości pracy”, ukazuje nie tylko najgłębsze, biblijne źródła pojmowania zagadnienia pracy człowieka, ale nade wszystko odsłania jej integralny związek z życiem wewnętrznym i pracą duchową. Podobna perspektywa będzie także obecna w jego dalszych wypowiedziach na temat ustawodawstwa pracy, którego praźródeł upatruje w samym Dekalogu [Wyszyński 1993, 397]. Na pytanie, do czego zmierza prawo pracy, odpowiadał, że ma ono na celu „bezpośrednie dobro pracowników, głównie robotników, a pośrednio zmierza ku dobru całego społeczeństwa" [tamże, 395]. Dla ks. Wyszyńskiego „słowo «robotnik» oznacza nadal i przede wszystkim - «człowiek». [...] Cały też człowiek musi być brany pod uwagę w organizacji warsztatu pracy i w panujących w nim stosunkach. Warsztat pracy powinien być przede wszystkim warsztatem ludzi pracujących. Stąd wszystkie urządzenia jego muszą liczyć się nie tylko z wymaganiami produkcji, ale też z potrzebami człowieka” [tamże, 380]. Wysokości ranga moralna, „zgodnego z prawem Bożym”, prawa pracy [tamże, 396] oznacza, że „ustawodawstwo pracy obowiązuje w sumieniu jako część prawa państwowego, jak każde rozumne prawo, wydane przez prawowitą władzę państwową" [tamże, 397]. To głęboko personalistyczne spojrzenie na problematykę pracy i prawa pracy nie traci nic ze swojej aktualności. Dla ks. Wyszyńskiego praca ma nade wszystko wymiar transcendentny, to znaczy przekracza porządek materialny, stanowi integralny element życia duchowego, realizuje Boży plan i wolę, choćby sam pracownik nie miał tego pełnej świadomości, jest także wartością religijną jako element modlitwy i uczestnictwa w dziele odkupienia i zbawienia [Bartnik 2001, 10].

Książka „Duch pracy ludzkiej” jest owocem wieloletnich przemyśleń ks. Wyszyńskiego, zwłaszcza z czasów wojny i w obliczu inwazji marksizmu do Polski. Problematyka pracy człowieka znajdowała się w centrum jego zainteresowań. Planował przygotować monografię habilitacyjną na temat „Środowisko moralne pracy fabrycznej" $\mathrm{z}$ bezpośrednimi odniesieniami do nowego nurtu w teologii, określanego jako „teologia rzeczywistości ziemskich” [tamże, 6; Nitecki 2007, 11]. Niestety materiały naukowe zebrane do habilitacji uległy zniszczeniu w czasie wojny, a późniejsze obowiązki biskupie uniemożliwiły podjęcia badań na nowo [Bartnik 2001, 7-8; Fortuniak 1971, 85]. Mimo, że dysponujemy licznymi opracowaniami na temat poszczególnych wątków nauczania społecznego ks. Wyszyńskiego, a badacze jego 
biografii dość wnikliwie potrafią opisywać poszczególne etapy jego życia, nadal brakuje analizy źródeł inspiracji głębokim zainteresowaniem problematyką pracy człowieka i ustawodawstwa pracy w świetle społecznego nauczania Kościoła. Powszechnie znana jest, zbliżona do formuły rozważań rekolekcyjnych, nakierowania na cele duszpasterskie, synteza myśli ks. Wyszyńskiego na temat zjawiska pracy człowieka w dziele „Duch pracy ludzkiej”. Odniesienia do problematyki pracy odnajdujemy także w powojennym, bogatym zbiorze homilii i wystąpień Księdza Prymasa, szczególnie w cyklu tzw. kazań świętokrzyskich [Wyszyński 1990, 581-82]. Wydaje się, że pomimo różnorodności opracowań naukowych na temat postaci i nauczania kard. S. Wyszyńskiego, istnieje potrzeba prowadzenia dalszego studium nad rozwojem jego myśli i intelektualnych inspiracji w okresie seminaryjnym i II RP, także w odniesieniu do problematyki pracy. Powyższa publikacja może stać się przyczynkiem do dyskusji naukowej, a w środowisku doktryny prawa pracy, interesującym materiałem poznawczym, ukazującym nieznane szerzej oblicze ks. Wyszyńskiego.

\section{ENCYKLIKA RERUM NOVARUM I PIERWSZE INSPIRACJE}

Gdy zastanawiamy się nad źródłami inspiracji ks. Wyszyńskiego nad zagadnieniem pracy, nie sposób pominąć najważniejszego dzieła współczesnej mu epoki, czyli encykliki Leona XIII Rerum novarum ${ }^{1}$. Był to dokument przełomowy i nowatorski pod każdym względem. Oto bowiem w centrum troski Kościoła znalazła się „kwestia robotnicza”, czyli problem wyzysku ludzi pracy w nowym, przemysłowym środowisku i nie mniej poważny problem ideologicznej instrumentalizacji postulatów ludzi świata pracy i kapitału².

Katolicka nauka społeczna rodzi się w określonym kontekście społeczno-gospodarczym, jako reakcja na skomplikowaną sytuację ludzi żyjących z pracy najemnej w XIX w. i na początku XX w. Rewolucja przemysłowa,

${ }^{1}$ Leo PP. XIII, Litterae encyclicae Sanctissimi D.N. Leonis Papae XIII de conditione opificum Rerum novarum (15.05.1891), ASS 23 (1890/91), s. 641-70; tekst polski w: Dokumenty nauki społecznej Kościoła, cz. 1, red. M. Radwan, Wydawnictwo KUL, Rzym-Lublin 1996, s. 63-92.

${ }^{2}$ Zob. https://www.vatican.va/roman_curia/pontifical_councils/justpeace/documents/ rc_pc_justpeace_doc_20060526_compendio-dott-soc_pl.html [dostęp: 10.05.2020]. 
obok niewątpliwego postępu cywilizacyjnego, przyniosła ogromne niepokoje społeczne robotników, którzy wraz ze swoimi rodzinami skazani byli na życie w tragicznych warunkach bytowych i socjalnych. Nieuregulowane w żaden sposób godziny pracy, brak ustalonych dni wolnych od pracy, nagminne korzystanie z niżej opłacanej pracy dzieci, brak regulacji dotyczących wypłaty wynagrodzenia, niebezpieczne dla zdrowia i życia warunki pracy, to tylko niektóre przykłady skrajnie trudnych sytuacji ówczesnych robotników. W dziewiętnastowiecznych krajach europejskich zakazana była działalność związków zawodowych i innych stowarzyszeń, które mogły być wyrazicielami interesów robotników. We Francji na mocy ustawy Le Chapelier z $1791 \mathrm{r}^{3}{ }^{3}$ wprowadzono obwarowany sankcjami karnymi zakaz organizowania się robotników w zrzeszenia zawodowe. Dodatkowo w epoce napoleońskiej ukazała się ustawa przewidująca karę aresztu do trzech miesięcy za zawiązywanie koalicji robotniczej lub organizowanie strajków. Przewidywała ona jednocześnie wprowadzenie specjalnych książeczek robotniczych, w których przedsiębiorcy wpisywali swoje opinie na temat pracowników. Obowiązek ich posiadania oznaczał ich uzależnienie od pracodawców oraz policyjną kontrolę nad nim. Ustawa ta została zniesiona dopiero w II poł. XIX w., a związki zawodowe zalegalizowane w 1884 r. na mocy tak zwanego prawa Waldecka-Rousseu ${ }^{4}$. Dopiero w 1871 r. na podstawie Trade Union Act ${ }^{5}$, brytyjscy związkowcy uzyskali prawo do działania. W podobny sposób kształtowała się sytuacja w innych krajach europejskich. Wszelkie próby państwowej ingerencji w sferę stosunków społecznogospodarczych czy ustawowych zmian mających na celu ucywilizowanie warunków pracy robotników spotykały się z oporem ze strony przedsiębiorców, którzy w duchu liberalnego fundamentalizmu argumentowali, iż jest to wbrew zasadom wolnego rynku i swobody zawierania umów. Fala strajków i niepokojów społecznych nie omijała także Polski. Jeden z najwcześniejszych dużych strajków w nowoczesnym przemyśle kapitalistycznym Królestwa wybuchł w 1871 r. w fabryce Lilpopa w Warszawie. W 1874 r. pierwszy raz doszło do jednoczesnego strajku kilku fabryk, a protest

${ }^{3}$ Le Chapelier (1791), https://institutions-professionnelles.fr/reperes/documents/1191791-la-loi-le-chapelier-interdit-les-corporations [dostęp: 20.03.2021].

${ }^{4}$ Loi Waldeck-Rousseau (1884), https://www.britannica.com/topic/Loi-WaldeckRousseau [dostęp: 20.03.2021].

${ }^{5}$ Trade Union Act (1871), https://www.ilo.org/dyn/natlex/docs/ELECTRONIC/98373 /117044/F1671923749/IRL98373.pdf [dostęp: 15.03.2021]. 
szybko stał się regularną częścią życia społecznego [Leszczyński 2020, 768]. Do najbardziej brutalnych starć przed rewolucją doszło w 1892 r. w Łodzi; ów „bunt łódzki” przygotował już grunt pod krwawe walki rewolucyjne z następnej dekady, do których doszło w latach 1905-1907.

Wszystko to spowodowało, że ludzie Kościoła, w tym świeccy, coraz większą uwagę zaczęli poświęcać problematyce społecznej ludzi pracy. Jednym z pionierów na tym polu był bp Moguncji Wilhelm von Ketteller, którego myśl i działalność wywarła ogromny wpływ na rozwój katolickiej nauki społecznej w całej Europie. Po nim kwestiami społecznymi zaczęli zajmować się takie postacie jak: ks. Adolf Kolping, o. Heinrich Pesch TJ, ks. Franz Hitze, w Austrii Adrien Albert Marie de Mun, a we Francji François-René de La Tour du Pin Chambly.

Encyklika Rerum novarum podaje krytyce dwa systemy społeczno-polityczne: socjalizm i liberalizm. Papież Leon XII czyni to jednak w sposób nowy i profetyczny. Od tej pory obrona godności człowieka, z którą łączą się zagadnienia prawa własności, zasady współpracy między klasami społecznymi, praw słabych i ubogich, obowiązków pracowników i pracodawców, praw zrzeszania się, , stały się nie tylko istotnym elementem nauczania Kościoła ${ }^{7}$, ale otworzyły drogę do rozwoju nowej dziedziny poznania naukowego określanej później jako Katolicka Nauka Społeczna.

Nie wiemy, kiedy dokładnie zrodziła się fascynacja ks. Wyszyńskiego nauczaniem społecznym Leona XIII. Z pewnością znane alumnowi Wyszyńskiemu były encykliki społeczne, a wśród nich, pierwszy tego typu dokument papieski Quanta cura (1864) Piusa IX, poprzedzający Rerum novarum. Ks. Wyszyński czytał zapewne inne encykliki Leona XIII: Diuturnum illud (1881) i Immortalne Dei (1885) i późniejsze dokumenty, jak encyklika Piusa X Il fermo proposito (1906), czy wydaną w okresie seminaryjnym Wyszyńskiego encyklikę Piusa XI Ubi Arcani Dei (1922). Nie sposób pominąć kolejnych istotnych dokumentów, jak wydana w rok w uzyskaniu święceń kapłańskich Wyszyńskiego, encyklika Piusa XI Quas

${ }^{6}$ Zob. https://www.vatican.va/roman_curia/pontifical_councils/justpeace/documents/ rc_pc_justpeace_doc_20060526_compendio-dott-soc_pl.html [dostęp: 10.05.2020].

${ }^{7}$ Ioannes Paulus PP. II, Litterae encyclicae venerabilibus in episcopatu Fratribus Clericisque et Religiosis Familiis, Ecclesiae Catholicae Fidelibus universis necnon bonae voluntatis hominibus saeculo ipso Encyclicis ab editis litteris «Rerum novarum» transacto Centesimus annus (01.05.1991), AAS 83 (1991), s. 793-867; tekst polski w: https://opoka.org.pl/biblioteka/W/WP/jan_pawel_ii/encykliki/centesimus_1.html [dostęp: 05.05.2021], nr 60. 
Primas, czy też kolejne: Divini Illius Magistri (1929), Casti connubii (1930), czy wreszcie Quadragesimo anno (1931). Papież Pius XI ponadto ogłosił encyklikę społeczną Divini Redemptoris (1937) o bezbożnym komunizmie [Strzeszewski 2012, 21].

Wiemy, że w okresie seminaryjnym ks. Wyszyńskiego we Włocławku program nauczania katolickiej nauki społecznej był bardzo ograniczony. To liczące ponad 450 lat seminarium duchowne, na początku XX w. było jednym z najważniejszych ośrodków formacyjnych i intelektualnych Kościoła katolickiego w Polsce. W latach 1908-1914 rektorem seminarium był ks. Idzi Radziszewski, późniejszy założyciel i pierwszy rektor Katolickiego Uniwersytetu Lubelskiego. W tym okresie pracował tam, jako profesor filozofii i nauk społecznych, ks. profesor Antoni Szymański. Osoba, która wywarła fundamentalny wpływ na kształtowanie się poglądów społecznych ks. Wyszyńskiego.

W Polsce pionierem badań w zakresie społecznego nauczania Kościoła był m.in. związany z papieżem Leonem XIII Edward Jaroszyński (18651907), którego opublikowana w 1901 r. praca pt. „Katolicyzm socyalny” [Jaroszyński 1908], uważana jest za umowny początek myśli chrześcijańsko-społecznej w Polsce [Jarocki 1964, 258] ${ }^{8}$. Oczywiście myśl ta sięga także wcześniejszego okresu międzypowstaniowego [Bender 1981a, 25]. O ile praca Edwarda Jaroszyńskiego znana była głównie w Galicji, tak w zaborze pruskim kluczową rolę odegrali ks. Kazimierz Zimmermann i ks. Piotr Wawrzyniak, którzy w 1901 r. założyli czasopismo „Ruch ChrześcijańskoSpołeczny". Było to pierwsze na ziemiach polskich czasopismo naukowe poświęcone idei i szerzeniu myśli chrześcijańsko-społecznej. Ks. Zimmermann w artykule tam opublikowanym w 1908 r. pt. „Znaczenie stanu robotniczego dla społeczeństwa i Kościoła”, w dość nowatorski sposób oceniał sytuację ówczesnego robotnika (23 lata przed wydaniem encykliki Quadragesimo anno). Cechą proletaryzmu była, jego zdaniem, „nie nędza, lecz niepewność jutra” [Zimmermann 1908, 387]. W podobny sposób, wiele lat później, problem ten ujmował ks. Szymański, który utożsamiał proletaryzm z niepewnością bytu, powołując się na Quadragesimo anno, encyklikę Piusa XI [Szymański 1925, 157]. Program reform społecznych, jakiego domagał się ks. Zimmermann, miał w pierwszym rzędzie swoje źródło w postulatach socjalnych i moralnych, a dopiero na drugim miejscu w sferze

\footnotetext{
${ }^{8}$ Pseud. Cz. Strzeszewskiego.
} 
reform gospodarczych [Strzeszewski i Banaszek 1981, 74]. Podobne spojrzenie w późniejszej swojej twórczości naukowej prezentował także ks. Wyszyński. Publicyści „Ruchu Chrześcijańsko-Społecznego” byli pod dużym wpływem niemieckiej szkoły chrześcijańsko-społecznej, zwłaszcza prac Augusta Lehmkuhlaina. Twierdził on m.in., że prawo pracy pochodzi z prawa naturalnego [tamże]. W podobny sposób po latach ks. Wyszyński przypomni, że „Katolicy powinni wiedzieć w prawie pracy dalszy ciąg prawodawstwa, zapoczątkowanego ongiś przez Boga; powinni wiedzieć upowszechnienie się ducha chrześcijańskiej miłości bliźniego, postęp moralności i Sprawiedliwości nakazanej przez Boga. Prawo pracy ma swój początek w Dekalogu" [Wyszyński 1993, 397].

Na terenie Królestwa, kilka lat później, w 1906 r. ks. Adam Woroniecki, późniejszy o. Jacek, dominikanin, rektor KUL, opublikował pierwszy zarys katolickiej akcji społecznej [Woroniecki 1906]. Rok później ukazała się kolejna praca autorstwa bł. ks. Jerzego Matulewicza - „Co kościół twierdzi o prawie własności”, opublikowana w Academia Caesarea Romano Catholica Ecclesiastica Petropolitana. Ten sam autor, pierwszy profesor nauk społecznych w Akademii Duchownej w Petersburgu, opublikował najważniejszą swoją pracę „Chrześcijańska teoria praw własności” [Matulewicz 1907]. Ks. Aleksander Wóycicki, następca ks. Matulewicza na katedrze w Petesburgu, ogłosił w 1915 r. swoją główną rozprawę „Instytucje fabryczne i społeczne w przemyśle Królestwa Polskiego", a w 1917 r. kolejne książki: „Dzieje klasy robotniczej w Królestwie Polskim”, „Chrześcijański ruch robotniczy w Królestwie Polskim” oraz „Demokracja Chrześcijańska w Polsce".

Zdaniem Ryszarda Bandera, rozwój chrześcijańskiej myśli społecznej w okresie po wydaniu encykliki Rerum novarum, wyprzedziła w Królestwie konkretna działalność społeczna duchowieństwa [Bender 1981b, 213]. A wśród niej postawy takich kapłanów jak: ks. Karol Blizinski, pionier „pracy misyjnej wśród klasy robotniczej”, a później ks. A. Gniazdowski i ks. Władysław Żaboklicki. Kapłani ci znani byli z tego, że odwiedzali fabryki, prowadzili nabożeństwa dostosowane do godzin wolnych od pracy w przemyśle, spieszyli z pomocą materialną robotnikom chorym i pozbawionym pracy i grupowali wokół Kościoła duże grono robotników i robotnic. Ówczesna hierarchia kościelna w Królestwie uważała wychodzenie duchowieństwa $\mathrm{z}$ inicjatywami społecznymi na teren robotniczy za rzecz dość ryzykowną. Pierwszy, który tego dokonał, czyli ks. Karol Bliziński, 
został przeniesiony do wiejskiej parafii. Zdaniem R. Bendera, encyklika Leona XIII Rerum novarum nie stanowiła w Królestwie przedmiotu żywego zainteresowania duchowieństwa i wiernych. W ówczesnej prasie katolickiej i publikacjach kościelnych brakowało jej szerszych analiz [tamże, 214]. Być może także i z tego powodu, szczególne zainteresowania intelektualne ks. Wyszyńskiego skłaniały się w kierunku nauczania społecznego Kościoła. Wiemy, że w późniejszym czasie ks. Wyszyński był gorliwym propagatorem współpracy ze stowarzyszeniami robotników chrześcijańskich i w okresie, kiedy pełnił rolę profesora we wrocławskim seminarium zachęcał kleryków do spotkań ze środowiskami robotniczymi.

\section{W SZKOLE KS. SZYMAŃSKIEGO}

Wydaje się, że najszersze inspiracje ks. Wyszyński czerpał z twórczości ks. Antoniego Szymańskiego. Podobnie jak ks. Wóycicki, swoją formację naukową zawdzięczał studiom filozofii i nauk społecznych w jednym z najważniejszych centrum myśli tomistycznej, w Wyższym Instytucie Filozoficznym Katolickiego Uniwersytetu w Louvain. Tam też uzyskał stopień doktora na podstawie rozprawy „La démocratie chrétienne en France”. Studia w Louvain ks. Szymański musiał odbywać pod przybranym nazwiskiem Antoniego Hoffena z obawy przed carskimi represjami. Pod tym nazwiskiem ukazały się też jego pisemne prace naukowe w języku francuskim [Peciakowski 2018]. Promotorem pracy doktorskiej ks. Szymańskiego był ks. prof. Maurice Defourne, wybitny znawca katolickiej nauki społecznej oraz późniejszy sekretarz Międzynarodowego Związku Badań Społecznych w Malines (Unii Mechlińskiej).

Ks. Wyszyński studiując $\mathrm{w}$ seminarium diecezjalnym we Włocławku, w jednym z czołowych ośrodków ówczesnej myśli katolickiej w Polsce, zapewne miał styczność z pionierskimi publikacjami ks. Szymańskiego (do 1918 r. wykładowcy seminarium we Włocławku), zwłaszcza z opublikowaną w 1913 r. książką pt. „Studya i Szkice Społecznie” (Biblioteka Dzieł Chrześcijańskich - Warszawa 1913). Autor w odważny i nowatorski sposób, inspirując się nauczaniem społecznym papieża Leona XIII, prezentuje trzy główne zagadnienia: 1) społeczna nauka Kościoła, 2) historia ruchu społecznego, 3) praca społeczna duchowieństwa [Szymański 1913a, 247]. W pierwszej części autor wyjaśnia szereg pojęć nauki społecznej Kościoła 
(np. różnice między demokracją chrześcijańską a socjalistyczną, zadania demokracji chrześcijańskiej, wskazania dotyczące pogłębienia katolickiego ruchu społecznego) w oparciu o encykliki papieskie: Rerum novarum (1891), Graves de communi (1901) i Singulari quadam (1912) [tamże, 20-27]. Część druga zawiera szczegółową historię ruchu społecznego (jego powstanie, rozwój w poszczególnych krajach), a zwłaszcza dzieje katolicyzmu społecznego i demokracji chrześcijańskiej. W części trzeciej autor przedstawia bardzo ważne zagadnienie angażowania się duchowieństwa w pracę społeczną [tamże, 197-228]. Powołując się na autorytet papieży Piusa X i Leona XIII, w trzeciej części dzieła, przekonuje, że „duchowieństwo ma nieść pomoc (red. w instytucjach społeczno-ekonomicznych) i to skuteczną, tak jednak, aby przez to nie zaniedbało swojego obowiązków, nie zawikłało się w sprawach świeckich i nie odpowiadało za finansowe kierownictwo i powodzenie instytucyi. Kapłan może więc być nie tylko członkiem zwyczajnym społeczno-ekonomicznym instytucyi, ale może brać udział w zarządzie, w komisyi rewizyjnej, wspólnie $\mathrm{z}$ innymi pracować dla osiągnięcia celu. Nadto, dodać możemy, kapłan powinien czynić pewien wybór między instytucjami i otaczać swoją opieką przede wszystkim te, których klientelę, stanowi ludność uboga, które mają na celu wyrwanie ludności z biedy i ekonomicznej nędzy, a która bez księdza nie mogłaby wcale albo prawie wcale funkcjynować" [tamże, 224]. Podobnie ks. Szymański, w okresie włocławskim, włączał się w działalność polityczną i społeczną. W lutym 1917 r. wszedł jako radny do Rady Miejskiej m. Włocławka, będącej pierwszą od ponad 50 lat reprezentacją mieszkańców miasta we władzach miejskich, i pełnił tę funkcję do końca swego pobytu we Włocławku (XI 1918). Ponadto sprawował funkcję przewodniczącego Zarządu Okręgowego Polskiej Macierzy Szkolnej we Włocławku (1917) [Pawlak 2011, 218-19].

Wracając do pierwszej części podręcznika z 1913 r. pt. „Demokracya chrześcijańska”, ks. Szymański, nawiązując do nauczania społecznego papieża Leona XIII, zwłaszcza w encyklikach Graves de communi z 18 stycznia 1901 r. i Rerum novarum z 1891 r., nakreśla swoisty program działania dla ówczesnych katolików, zwłaszcza kapłanów, w sferze, jak na ówczesne czasy bardzo kontrowersyjnej, czyli ekonomii społecznej i tzw. kwestii robotniczej. Jak wyjaśniał ks. Szymański, „naprzeciw robocie wywrotowej naprzeciw rewolucyi społecznej, która się tworzyła powoli, jako konieczny ciąg dalszy rewolucyi religijnej z XVI w. i politycznej w XVIII, Ojciec Św. chciał postawić armię dobrze zorganizowaną, mocno czynem społecznym 
i spokojną duchem katolickim, nadprzyrodzonym, oraz miłością wzajemną" [Szymański 1913a, 4].

Po ukazaniu się encykliki Rerum novarum, w różnorodnych kręgach ówczesnej inteligencji katolickiej, zwłaszcza we Francji i Włoszech, podejmowano pierwsze próby opracowania programów społecznych, które zawierałyby istotę przesłania papieża Leona XIII. Początkowo nie dawano żadnej nazwy tej działalności społecznej, katolickiej, skierowanej ku „obronie ludu, który często wystawiony jest niemniej na zasadzki i niebezpieczeństwa moralne, jak i na nędzę i próby losu" [Szymański 1913a, 6]. Pojawiały się takie określenia, jak „socjalizm chrześcijański”, „chrześcijaństwo społeczne”, czy „chrześcijańska akcya ludowa”, które nie zyskały aprobaty Ojca Świętego [tamże]. Pojawiło się także pojęcie „demokracyi chrześcijańskiej”, które mimo licznych głosów polemicznych, w opinii papieża Leona XIII, najbliżej oddawało treść wspomnianej encykliki. Jak wyjaśnia ks. Szymański, nazwę tę po raz pierwszy sformułowano na kongresie w Malines w 1891 r., gdzie ją głosił poseł belgijski (Jouris) Helleputte. Szeroko wówczas dyskutowano, czy „demokracya chrześcijańska” powinna stać na straży własnej, rzymskokatolickiej wyznaniowości, czy też powinna „bronić neutralności wyznaniowej” [tamże, 9]. Czy powinna ona przekształcić się w zwarty program polityczny („czy demokracya dąży do gminowładztwa (civitas popularis) lub do zmiany formy rządu”?) czy zasięg jej oddziaływania powinien ograniczać się wyłącznie do „dobra jednej warstwy, mianowicie ludu”, i czy „zmierza do wybicia się z pod prawowitej władzy duchowej lub świeckiej?” [tamże].

W obliczu narastających sporów wokół tego, czym powinna być „demokracya chrześcijańska”, w tej sprawie ponownie zabrał głos Leon XIII. Zaprezentował w encyklice Graves de communi program „demokracyi chrześcijańskiej”, który nie miał być formą stricte zaangażowania politycznego, lecz postępowym programem społecznym dla ówczesnych katolików. Pierwszy element tego nowatorskiego projektu to zalecenie, że „demokracya chrześcijańska [...] musi mieć za podstawę zasady wiary Bożej, w taki sposób zmierzając do dobra warstw najniższych, aby odpowiednio doskonalić dusze, do wiecznych rzeczy stworzone" [tamże, 11]. Programem społecznym ma być zatem zasada sprawiedliwości, która „ma przyznać nietykalność prawu nabywania i posiadania; musi zachowywać nierówność stanów, jako właściwość dobrze urządzonego społeczeństwa; wreszcie ma zgadzać się z tą formą i właściwością społeczności ludzkiej, jakiej nadał 
Boski jej Twórca” [tamże]. Niewątpliwie akceptacja prawa posiadania i przeciwstawienie się w walce klasowej i „oderwanie się” od bieżącego zaangażowania politycznego, czyniły ten program bardziej uniwersalnym i powszechnym. Siłą tego programu był solidaryzm społeczny, którego celem jest zachowanie „owego węzła solidarności, który ludzi łączy” [tamże, 13]. W zamyśle papieża Leona XIII „demokracya chrześcijańska” nie stawia sobie za cel zmiany ustroju politycznego na rzecz republikańskiej formy rządu [tamże, 12], nie jest też ruchem politycznym - „w każdej ostatecznie formie państwowej obywatele mogą i powinni trzymać się tych przepisów, które im nakazuje miłować Boga nade wszystko, bliźniego zaś jak siebie samego" [tamże]. Zatem, „demokracya chrześcijańska” - jak objaśniał to ks. Szymański - „nie może uprawiać polityki, zmierzających do zmiany formy rządu lub do koniecznego zaprowadzenia republiki, nie może wymagać od swoich członków takiego lub innego credo politycznego" [tamże]. Treścią „demokracyi chrzescijańskiej” jest „praca ducha [...], demokracya socyalistyczna, zaczyna od materii, od zmiany właścicieli ziemi i narzędzi wytwarzania, od zmiany sposobu posiadania. Demokracya chrześcijańska, zaczyna od ducha, od Boga i od duszy ludzkiej; najpierw chce zmiany w duszach, a potem chce zmiany w stosunkach społecznych. Demokracya socyalistyczna chce dojść do szczęścia ogólnego przez urządzenie stosunków materyalnych i zrównanie wszystkich obywateli do jednego poziomu, czyniąc z nich urzędników i funkcjonariuszy. Demokracya chrześcijańska chce dojść do dobra pospolitego przez pracę ducha i ofiarę" [tamże, 15].

Idee „demokracyi chrześcijańskiej” stały się programem działania także dla ks. Wyszyńskiego, który w trakcie studiów we Włocławku nie mógł sobie zdawać sprawy jak niektóre z myśli papieża Leona XIII będą dla niego istotne, zwłaszcza w okresach dwóch totalitaryzmów. Trudno nie doszukać się analogii do powyższych myśli, gdy podejmiemy lekturę jednego z najważniejszych opracowań ks. Wyszyńskiego zatytułowanego „Duch pracy ludzkiej. Myśli o wartości pracy”. To wybitne dzieło z zakresu teologii duchowości, zawiera oryginalną refleksję na temat potrzeby łączenia w osobie pracującego zarówno wymiaru pracy wewnętrznej, jak i zewnętrznej. Myśl tę, w nieco zmienionej formie, w późniejszym okresie czasu, zawrze w encyklice Laborem exercens Jan Paweł II, określając ją jako pracę podmiotową i przedmiotową. Rozważania ks. Wyszyńskiego powstały „w latach niszczenia przez najeźdźców dorobku pracy narodowej”, jak wyjaśnia sam Autor we wstępie do pierwszego wydania z marca 1946 r. W okresie 
stalinowskim, we wstępie do trzeciego wydania z 1953 r., z jeszcze większą siłą przywoła ów „naturalny stan rzeczy”, że „nieprzerwany trud pracy wiąże nieustannie najwartościowsze siły fizyczne i władze duchowe człowieka”.

Obok wymiaru duchowego, jak wyjaśnia ks. A. Szymański, „demokracya chrześcijańska” może być postrzegana jako swoisty „ustrój społeczny”, w którym „wszystkie warstwy społeczne, wyższe i niższe, a każda w swoim zakresie, pracują dla dobra ogólnego, przede wszystkim dla dobra poniżonych i opuszczonych, aby ich podnieść na duchu, aby ich życie uczynić znośniejszym, godnym człowieka i chrześcijanina; taki ustrój społeczny, w którym chodzi nie tylko o oddanie każdemu sprawiedliwości, ale także o rozszerzenie praw słuszności, ciepła miłości, aby wszyscy czuli się jako bracia, równi wobec Boga synowie Boży, aby się jako bracia społecznie w Panu miłowali" [tamże, 21]. Potrzeba zbudowania chrześcijańskiej, jak współcześnie moglibyśmy dodać, personalistycznej więzi w środowisku pracy, opartej na ewangelicznej zasadzie miłości, wydaje się być najważniejszym punktem społecznego programu działania księdza Wyszyńskiego. „Demokracya chrześcijańska” szczególną potrzebę wiązała z koniecznością „pogłębienia ruchu społecznego katolickiego. Dotyczą one udziału klas wyższych, stosunku do istniejącej już instytucyj, zachowania jedności, udziału duchowieństwa, sposobu nauczania, posłuszeństwa biskupom i dawania przykładu". Jak wyjaśniał ks. Szymański w komentarzu do Graves de communi, „Miłosierdzie więc chrześcijańskie może być odręczne i chwilowe, może też być zorganizowane w stowarzyszenia i związki, może samo wyszukiwać biednych, zamiast żeby biedni mieli jałomużny szukać, może zwrócić się raczej do usuwania przyczyny ubóstwa, do zapobiegania i nieszczęściu, aniżeli do leczeniu objawów" [tamże, 23]. Celem pracy nad ludem ma być zatem „nie tylko dopomożenie, ale także usamowolnienie, aby przynajmniej jednostki bystrzejsze, zdolniejsze i pracowitsze mogły później same sobie wystarczyć”. Przeto Ojciec Święty chwali urządzenia miłosierne, ale też dodaje: „Jeszcze chwalebniejsza jest dążność do zapewnienia robotników i rzemieślników w oszczędności i przezorności, ażeby z latami sami sobie, przynajmniej częściowo, dali radę” [tamże]. „Demokracya chrześcijańska” stała się także programem działania dla ks. Wyszyńskiego, zgodnie z poleceniem Leona XIII, „A żeby wszystkie stowarzyszenia, zachowując odrębność, zmierzały do celu pod sterem jednej i tej samej siły kierowniczej [...]”, zachęca też duchowieństwo „aby brało gorliwy udział w pracach demokracji chrześcijańskiej; A żeby pamiętano o tym iż tak jed- 
nostki, jak całe stowarzyszenia, we wszystkim, co w tej sprawie zamierzają, obowiązane są do zupełnej uległości powadze biskupów; na pamięć przywodzi obowiązek dawanie dobrego przykładu a biskupom - potrzebę stworzania akcyi społecznej katolickiej i kierowanie nią" [tamże].

W 1916 r. opublikowana została we Włocławku pierwsza synteza katolickiej nauki społecznej autorstwa ks. Szymańskiego pt. „Zagadnienia społeczne". Autor w nowatorski sposób wyjaśniał kwestie metodologiczne katolickiej nauki społecznej. A więc określenie ekonomii, charakter praw ekonomicznych, stosunek ekonomii do nauki chrześcijańskiej, zagadnienie społeczne a ekonomia. Następnie zaprezentował nauczanie Kościoła dotyczące ówczesnych przemian społeczno-gospodarczych. Jak wyjaśniał - „Kościół ma obowiązek zająć się zagadnieniem społecznym. Zagadnienie to bowiem co do swej istoty jest moralnym i religijnym, bez udziału religii załatwione być nie może, stróżem zaś i nauczycielem religii jest Kościół" [Szymański 1916, 17-26]. Wprawdzie Kościół ma do spełnienia zadania nadprzyrodzone, ale pośrednio poprzez swoją naukę przyczynia się do rozwoju ekonomicznego, bezpośrednio zaś do utrzymania społecznego ładu i zgody. To dzięki nauce społecznej Kościoła rzeczywistość społeczna ma być tak kształtowana, aby była godna człowieka. Fundamentem zaś ustroju ekonomiczno-społecznego powinny być sprawiedliwość i miłość. Ważne zagadnienia przedstawiane $\mathrm{w}$ pracy to: funkcjonowanie społeczeństwa, instytucji społecznych, a zwłaszcza podstawy organizacji gospodarczej. Kolejne problemy społeczne dotyczą przemysłu, rzemiosła, handlu i rolnictwa. W najobszerniejszej części swego dzieła (trzeciej), dotyczącej tzw. polityki społecznej, ks. Szymański poddał analizie między innymi problem ochrony zdrowia pracowników, pracy najemnej, oświaty i ubezpieczeń społecznych. Warto podkreślić, że jako jeden z pierwszych autorów twierdził, że związki zawodowe, mające na celu zabezpieczenie praw pracowników, powinny być niezależne od wszelkich organizacji państwowych (politycznych) [Pawlak 2011, 325]. Ks. Szymański omawia również różnego typu stowarzyszenia zawodowe robotników powstające w wielu krajach. Przedstawia także ówczesny polski ruch zawodowy [Szymański 1916, 331-36].

Zainteresowania ks. Wyszyńskiego związane z szeroko pojmowanym nauczeniem społecznym Kościoła mogły się także rozwijać dzięki lekturze „Ateneum Kapłańskiego”, czasopisma założonego we Włocławku w 1909 r. przez ks. Idziego Radziszewskiego. Należy odnotować, że w okresie redaktorstwa ks. prof. A. Szymańskiego czasopismo dużą uwagę poświęcało 
naukom społecznym. Obok opracowań umieszczanych w dziale „Rozprawy”, problematyka ta zajmowała dział pt. „Ruch społeczny”. Sam ks. Szymański w latach 1909-1918 opublikował w „Ateneum Kapłańskim” około 60 swoich opracowań, nie licząc licznych recenzji i not bibliograficznych, nieraz podpisywanych kryptonimami (Dr A. S-ki, Dr S-ki, X. A. S, Ks. A. S., A. S., Sz., As., Aes) [Pawlak 2011, 215].

Inna ważna lektura to „Przegląd Katolicki”, czasopismo katolickie (w różnych okresach tygodnik lub dwutygodnik) wydawane przez Archidiecezję Warszawską w Warszawie od 1863 r. Tam mógł odnaleźć tłumaczenia artykułów ukazujących się na Zachodzie. Dotyczyły one najczęściej filozofii świętego Tomasza, z nowszych myślicieli - Frédérica Le Playa czy Bp. Wilhelma von Kettelera. Warto odnotować, że to właśnie w „Przeglądzie Katolickim” opublikowana została encyklika Leona XIII Rerum novarum, do której, ówczesny redaktor naczelny, ks. Antoni Szymański, dał pierwsze tłumaczenie na język Polski [Bender 1981b, 213].

W latach 1925-1929 ks. Wyszyński kontynuował naukę na Wydziale Prawa Kanonicznego, a także na Wydziale Prawa i Nauk Społeczno-Ekonomicznych KUL. Decyzja o wyborze studiów prawa kanonicznego ks. Wyszyńskiego nie wynikała zapewne $\mathrm{z}$ jego bezpośrednich zainteresowań, a raczej z pewnej pragmatyki, jaką kierowały się władze kościelne. Niewątpliwie ta dziedzina wiedzy była szczególnie przydatna w działalności kościelnej, stworzyła szerokie możliwości pracy w diecezji włocławskiej. W nieco innym kierunku szły zainteresowania i predyspozycje ks. Wyszyńskiego. Skłaniały się one raczej ku studium z zakresu nauk społecznych, interesowała go przede wszystkim dopiero co kształtująca się w Polsce katolicka nauka społeczna. Zdaniem P. Raina, dylemat ten pomógł rozwiązać ks. A. Szymański, który mając świadomość początkowego zaledwie jeszcze rozwoju chrześcijańskiej refleksji naukowej nad problematyką społeczną oraz związana z tym jej słabość jako odrębnej dziedziny nauk kościelnych i to zarówno na zachodzie Europy, a tym bardziej w uczelniach polskich, zasugerował takie a nie inne rozwiązanie [Raina 2006, 27; Nitecki 2006, 16-17]. Jak się wydaje, w opinii ks. Szymańskiego, formacja prawnicza pozwala osiągnąć większą precyzję myślenia, a studia z zakresu nauk społecznych pogłębiają intelektualną wrażliwość na najważniejsze problemy życia publicznego [Nitecki 2006, 18].

Wśród profesorów Katolickiego Uniwersytetu Lubelskiego to właśnie ks. Szymański był jednym z tych, którzy wywarli największy wpływ na księ- 
dza Wyszyńskiego podczas jego studiów. Należy odnotować, że w 1925 r. wydane zastało najbardziej znane dzieło ks. Szymańskiego pt. „Polityka społeczna”, pierwszy podręcznik polityki społecznej napisany w języku polskim. Rok 1925 jest to także data rozpoczęcia studiów doktoranckich przez ks. Wyszyńskiego na KUL. Od pierwszego roku studiów doktoranckich (mimo, że praca doktorska ks. Prymasa dotyczyła prawa kanonicznego) uczestniczył w wykładach ks. prof. A. Szymańskiego na temat kapitalizmu i kolektywizacji, ustawodawstwa pracy, ubezpieczeń społecznych, teorii polityki społecznej i socjologii, a od czwartego roku studiów brał udział w kierowanym przez niego seminarium z zakresu polityki społecznej [Sitarz 2017, 81-101].

\section{OKRES PO STUDIACH DOKTORANCKICH}

Patrząc na życie i działalność ks. Wyszyńskiego w okresie międzywojennym, po ukończeniu studiów doktoranckich na Katolickim Uniwersytecie Lubelskim, dostrzec możemy szereg aktywności inspirowanych myślą księdza Szymańskiego. W roku akademickim 1929/30 ks. Wyszyński uzyskał stypendium naukowe, które umożliwiło mu bezpośrednie zapoznanie się z sytuacją katolicyzmu społecznego w takich krajach jak Austria, Włochy, Francja, Belgia i Holandia. Owocem tej podróży była publikacja pod tytułem „Główne typy Akcji Katolickiej za granicą”, którą ks. Wyszyński wydał w Lublinie w $1931 \mathrm{r}$. W opracowaniu tym poddawał analizie ówczesne prądy ideologiczne i ustroje społeczne, działalność katolickich organizacji społecznych oraz zrzeszeń robotniczych i młodzieżowych, w tym także stan i metody nauczania katolickiej nauki społecznej [Nitecki 2007, 83].

W okresie międzywojennym ks. Wyszyński opracowuje swoje kolejne artykuły z zakresu katolickiej nauki społecznej. Podejmuje też przygotowania do pracy habilitacyjnej na temat moralnych aspektów pracy w środowisku robotniczym. Okres II wojny światowej uniemożliwił ks. Wyszyńskiemu ukończenie pracy naukowej.

Po powrocie S. Wyszyńskiego do Włocławka zaczął on pełnić wiele funkcji, między innymi wicekustosza Bazyliki Katedralnej, redaktora naczelnego, istniejącego po dziś dzień „Ateneum Kapłańskiego”, czy też wykładowcy nauk społecznych w Wyższym Seminarium Duchownym we Włocławku. Wykładał tam m.in. historię etyki katolickiej i społecznej, 
ekonomię społeczną, system katolickiej nauki społecznej, socjologię stosowaną i Akcję katolicką. Idąc za wskazaniami swojego mistrza podjął współpracę z Chrześcijańskim Uniwersytetem Robotniczym - w domu robotniczym imienia Piusa XI we Włocławku. Organizował tam cykle wykładów na tematy społeczne, zwłaszcza na tematy związane z historią i funkcjonowaniem ruchu chrześcijańsko-społecznego na świecie [Raina 2006, 51]. Znany był także $\mathrm{z}$ tego, że angażował alumnów włocławskiego seminarium do pracy nie tylko $\mathrm{w}$ ramach chrześcijańskiego uniwersytetu robotniczego, ale także zapraszał ich do współpracy z chrześcijańskimi związkami zawodowymi [tamże, 52].

W 1937 r. ks. Wyszyński uzyskał powołanie do Rady Społecznej przy prymasie Polski. Kardynał August Hlond powołał tę Radę na polecenie papieża Piusa XI jako instytucję naukowo-programową. Kierowała ona między innymi całą prasą katolicką, liczącą ponad 300 tytułów [tamże, 56]. Prezesem Rady mianowano ks. A. Szymańskiego.

Rada ta miała propagować społeczne nauczanie Kościoła, zwłaszcza w kontekście opublikowanej w 1931 r. encykliki Quadragesimo anno papieża Piusa XI. Rada podejmowała aktualne problemy społeczno-gospodarcze ostatnich lat II Rzeczypospolitej, w ówczesnym świecie narastał wówczas kryzys gospodarczy, w obliczu którego papież wzywał do reformy systemu kapitalistycznego, poprawę sytuacji materialnej ludzi pracy tak, by wynagrodzenie zapewniało zaspokojenie potrzeb rodziny. „Supremacja gospodarcza, która w ostatnich czasach zajęła miejsce wolnej konkurencji [...] stanowi jakby siłę i potęgę wybuchającą; aby wyszła na korzyść ludzkości, musi być silnie okiełznana i mądrze kierowana; nie może zaś ani okiełznać się ani sobą kierować sama. Potrzeba więc wyższych i szlachetniejszych sił, które by supremację gospodarczą mocną i roztropną rządziły ręką: są nimi sprawiedliwość i miłość społeczna. Dlatego z nieubłaganą należy koniecznością urządzenia państwowe a tym samym urządzenia całego życia społecznego tym zaprawić poczuciem sprawiedliwości, które by stało się twórczym, czyli utworzyło porządek prawno-społeczny, kształtujący niejako całe życie gospodarcze"

\footnotetext{
${ }^{9}$ Pius PP. XI, Litterae encyclicae de ordine sociali instaurando et ad evangelicae legis normam perficiendo, in annum XL post editas Leonis XIII litteras encyclicas «Rerum novarum» Quadragesimo anno (15.05.1931), AAS 23 (1931), s. 177-228; tekst polski w: http://ptm.rel.pl/czytelnia/dokumenty/dokumenty-papieskie/49-pius-xi/247encyklika-quadragesimo-anno.html [dostęp: 20.03.2021], nr 89.
} 
Rada Społeczna przy Prymasie Polski opracowała szereg dokumentów, jak: „Wytyczne w sprawie organizacji zawodowej społeczeństwa” (1935), „Deklaracja w sprawie stanu gospodarczo-społecznego wsi polskiej” (1937), „Deklaracja o uwłaszczeniu pracy” (1939).

W sprawie organizacji zawodowych społeczeństwa Rada poddawała krytyce inkluzywny rozwój związków zawodowych bez zachowania należytej równowagi w reprezentacji poszczególnych grup społecznych w środowisku pracy. Rada podkreślała potrzebę nadania właściwych ram prawnych swoistym naturalnym wspólnotom tworzącym społeczność środowiska pracy, z zachowaniem ich odrębności od innych, dostrzegając naturalne współzawodnictwo i współpracę, wzajemne zależności i podporządkowania. Tej faktycznie wspólnocie interesów zawodowych należy dać formę prawną, gdyż zdaniem Rady inaczej nie zapewni się porządku i ładu społecznego. Rada podkreślała szczególne wyzwania związane z kształtowaniem się organizacji pracodawców, którą określała jako korporację zawodową. Zdaniem Rady - „tej faktycznej wspólnocie interesów zawodowych należy dać formę prawną, gdyż inaczej nie zapewni się porządku i ładu społecznego. Korporacja jest formą prawną stanu zawodowego. Nie spełni ona swego zadania, jeśli nie obejmie wszystkich tych, którzy wykonują dany zawód, jak gmina obejmuje wszystkich mieszkańców danego okręgu. Korporację należy uznać z natury rzeczy za instytucję prawa publicznego. Rada opowiadała się za utworzeniem ustroju opartego na korporacyjnej organizacji zawodów i nadaniu społeczeństwu cech jednolitego organizmu społecznego, a przez to przezwyciężenie różnic klasowych i ugruntowanie pokoju społecznego, który wówczas określano jako «spójnię», a której fundamentem powinno być odrodzenie chrześcijańskich obyczajów w środowisku pracy”. Tym samym Rada sprzeciwiała się oparciu stosunków społeczno-gospodarczych i prawnych na walce klasowej. Sprzeciwiała się systemowi organizacji ruchu związkowego w oparciu o model monopolistyczny (jeden wspólny związek zawodowy dla wszystkich pracowników). Pracownikom należy bowiem zapewnić swobodę organizacji związków zawodowych, zgodnie z zasadą, że prawo przyrodzone daje człowiekowi swobodę zrzeszania się. Rada sprzeciwiała się tendencji kilku państw Europy polegającej na monopolizacji organizacji zawodowej i uczynieniu z niej narzędzia politycznego w rękach rządu. Wówczas „naturalne prawo jednostki do zrzeszania się czyni one prawie iluzorycznym, odbierają swobodę ruchów społeczeństwu na tak ważnym odcinku życia zbiorowego, jak życie gospodarcze, które 
w dodatku poddają fluktuacjom nastrojów politycznych, zmieniających się ciągle w kołach rządowych".

Ponadto Rada opowiadała się za stworzeniem realnych warunków dla uwłaszczenia pracy, które miały stanowić antidotum na rozwój proletaryzmu. Można powiedzieć, że był to jeden z najbardziej istotnych elementów doktryny rozwijającej się wówczas Katolickiej Nauki Społecznej. W deklaracji z 1939 r. „O uwłaszczeniu pracy” Rada wyjaśniała, że „zjawisko proletaryzmu polega na niedostatecznym zaspokojeniu potrzeb gospodarczych oraz niepewności warunków życiowych pracownika i jego rodziny. Proletaryzm krępuje rozwój moralny oraz osłabia zmysł gospodarczy (przezorność i przedsiębiorczość) warstw pracujących, stwarza z nich element podatny dla wszelkich ruchów rewolucyjno-socjalnych, a zwłaszcza dla agitacji komunistycznej” (s. 1). Zdaniem Rady, wśród przyczyn proletaryzmu znajdują się: a) zbyt niski poziom niektórych grup płac, b) brak rozpowszechnienia własności dochodowej (lub przynajmniej dóbr kapitałowych), c) niedostateczny poziom rozwoju wytwórczości. Dlatego też w programie Rady, obok popierania powstawania i rozwoju istniejących związków zawodowych (s. 3), znalazły się postulaty poprawy sytuacji materialnej robotników i pracowników. W tym m.in. popieranie w granicach możliwości technicznych i warunków gospodarczych organizacji samodzielnych warsztatów rzemieślniczych oraz rozwój drobnego kupiectwa; dążenie do upowszechnienia płac rodzinnych, jak również podniesienia skali zarobków i ograniczenia czasu pracy odpowiednio do wymagań rentowności przedsiębiorstwa i zdolności wytwórczej pracownika; wyposażenie w miarę możliwości pracowników wielkich zakładów wytwórczych w parcele gruntowe lub przynajmniej ogródki działkowe i własne domy; może to nastąpić w drodze uruchomienia długoterminowego kredytu lub w ostateczności w drodze przymusowej oszczędności pod kontrolą zorganizowanego zawodu; dążenie do zniesienia systemu koszarowego mieszkań robotniczych na rzecz jedno lub parorodzinnych domów z ogródkami, w wypadkach gdy pomieszczenie dostarcza pracodawca; dążenie do możliwie wielostronnego przygotowania fachowego pracowników celem zabezpieczenia ich przed niebezpieczeństwem bezrobocia branżowego; czy też podejmowanie starania w kierunku częściowego usamodzielnienia robotników przez stworzenie dla nich dodatkowych źródeł zarobkowych (s. 3). W tym ostatnim aspekcie, „należy dążyć do tego «by umowa o najem pracy była w granicach możliwości uzupełniona umową spółkową» (Quad. Anno). Może to być wprowadzone w naj- 
szerszym zakresie w przedsiębiorstwach, będących własnością towarzystw akcyjnych, natomiast napotyka na wielkie trudności $\mathrm{w}$ firmach prywatnych. Spośród wszelkich form udziału pracowników w własności przedsiębiorstwa za najbardziej korzystny należy uznać system przymusowej oszczędności na zakup akcji przedsiębiorstwa. Celem uniknięcia przedwczesnej sprzedaży winny by one umieszczone na zablokowanym rachunku pracownika i wydawane tylko zgodnie z planem oszczędności pod kontrolą zorganizowanego zawodu" (s. 3). Walka z proletaryzmem w opinii Rady powinna nastąpić jedynie w ustroju stanowo-zawodowym, którego główne zasady Pius XI wskazał w encyklice Quadragesimo anno, czyli poprzez zapewnienie każdemu pracownikowi dostatecznych środków nie tylko dla zaspokojenia „konieczności życiowych i potrzeb pewnej godności”, ale umożliwienie mu także wzniesienia się „na wyższy stopień dobrobytu i kultury” (Quadragesimo anno).

\section{PRACA LUDZKA I PRAWO PRACY W REFLEKSJI KS. WYSZYŃSKIEGO}

Swoista synteza myśli ks. Wyszyńskiego na temat katolickiej nauki społecznej znajduje się w opublikowanym przez Wydawnictwo KUL skrypcie pt. „Chrześcijańska doktryna społeczna”. Odnajdujemy tam cenny zbiór przemyśleń, ujętych w formie cyklu wykładów, skierowanych w roku akademickim 1947/1948 do studentów ekonomii KUL, na temat źródeł i rozwoju tej nowej dziedziny wiedzy. W środowisku naukowym KUL, ks. dr Stefan Wyszyński traktowany jest jako prekursor lubelskiej szkoły katolickiej nauki społecznej [Fel 2020, 179]. Mimo, że jest to opracowanie stosunkowo niewielkich rozmiarów, i zawiera wszelkie elementy rzetelnie opracowanej propedeutyki katolickiej nauki społecznej, stanowi próbę syntezy stanu wiedzy na temat źródeł społecznego nauczania Kościoła, w trudnym okresie powojennej odbudowy. Próbę całościowego ujęcia i tworzenia metodologicznych podstaw do kształtowania katolickiej nauki społecznej, jako odrębnej dyscypliny naukowej, podejmował kilka lat wcześniej, ks. Antoni Szymański. Ostatnie z jego dzieł, zatytułowane „Zagadnienia społeczne”, opublikowane w 1939 r. nakładem Uniwersyteckiego Towarzystwa Wiedzy Chrześcijańskiej (wyd. III przerobione) to opracowanie skierowane przede wszystkim do współczesnej autorowi inteligencji katolickiej, zwłaszcza do 
„kleryków w seminariach i dla duchowieństwa” [Szymański 1939, 1]. Ks. Wyszyński w swoim skrypcie wyraźnie nawiązuje do dzieła ks. Szymańskiego. W podobny sposób odczytuje źródła istnienia katolickiej nauki społecznej, którymi są, podobnie jak całego katolicyzmu i chrześcijaństwa, „prawdy teologiczne, objawione, a więc dobro religijne i wiążące się z nimi prawdy moralne" [Wyszyński 2020, 17; Szymański 1939, 1]. Kościół nie tworzy zatem doktryn i systemów społeczno-gospodarczych. Jak przekonuje we wstępie do swoich wykładów ks. Wyszyński - „żaden z istniejących systemów gospodarczych, nie może być uznany za wyraziciela nauki Kościoła. Każdy będzie zbyt wąski, aby zamknął w sobie całą treść katolicyzmu" [Wyszyński 2020, 18].

Ks. Wyszyński starał się jednak wypracować własną drogę, która nie była związana bezpośrednio preferowaną przez ks. Szymańskiego socjologią katolicką. Preferował on uprawianie katolickiej nauki społecznej głównie $\mathrm{w}$ aspekcie duszpasterskim, jako wskazania dotyczące chrześcijańskich podstaw życia publicznego. Ks. dr S. Wyszyński nie widział siebie jako socjologa w tradycyjnym znaczeniu i rzeczywiście tak rozumianym socjologiem nie był. Był teologiem. On sam, nawiązując do dyskusji naukowych w okresie międzywojennym na temat tożsamości katolickiej nauki społecznej, stwierdził wiele lat później, że socjologią zajmował się „tylko przejściowo, pod wpływem księdza rektora Antoniego Szymańskiego na KUL. On to - wspominał - chciał ze mnie zrobić socjologa, a ja się broniłem, chcąc pozostać przy katolickiej nauce społecznej i jej dochować wierności. Starannie rozróżniam katolicką naukę społeczną czy - jak niektórzy mówili, zwłaszcza Niemcy - katolicką etykę społeczną od socjologii”. „Przed wojną zajmowałem się metodologią nauk katolicko-społecznych, też pod kierunkiem księdza prof. Szymańskiego. W tym celu jeździłem za granicę dla studiów porównawczych na terenie Itali, Austrii, Francji, Belgii i Holandii. Przemierzyłem te tereny, aby zebrać materiał porównawczy do metodologii katolickiej nauki społecznej. Później, gdy już rozpocząłem wykłady nauk społecznych w Seminarium włocławskim w roku 1930, rozróżniałem bardzo wyraźnie między katolicką nauką społeczną a socjologią" [Wyszyński 1990, 702]. To bardziej teologiczne i duszpasterskie niż filozoficzne i społeczne nachylenie, w odniesieniu do problematyki życia publicznego, widać było wyraźnie w prezentowanych jego uwagach dotyczących zmian w podręczniku ks. Szymańskiego, a także w jego publikacjach z tamtego okresu. Należy wymienić przede wszystkim artykuły: „Główne 
podstawy przebudowy ustroju społecznego” (Włocławek 1933); „Zasięg i charakter zainteresowań katolickiej myśli społecznej” (Poznań 1937); „Stanowisko i zadania duszpasterza wobec współczesnych ruchów społecznych” (Płock 1938); „Co duszpasterz może uczynić dla urzeczywistnienia ustroju korporacyjnego" (Lublin 1939). W uwagach do ostatniego wydania podręcznika ks. Szymańskiego proponował w ramach prezentacji zasad solidaryzmu chrześcijańskiego wprowadzić szersze omówienie teologicznych źródeł katolickiej nauki społecznej, a więc Pisma Świętego, Tradycji kościelnej, dzieł Ojców Kościoła, teologów moralistów, zwłaszcza św. Tomasza z Akwinu i dokumentów Stolicy Apostolskiej. Ma to doniosłe znaczenie - uzasadniał - przy późniejszym wnioskowaniu. Jednocześnie w oczach słuchaczy wykładów ujawnia autorytet nauki katolicko-społecznej. Najwięcej uwagi poświęcił, w swych sugestiach, części drugiej, omawiającej założenia gospodarcze. W tym zakresie, nawiązując do relacji ekonomii i etyki, proponował przede wszystkim rozwinięcie problematyki zależności życia gospodarczego od etyki religijnej i podkreślenie roli teologii moralnej w naukach społecznych [Nitecki 2007, 221].

W podobny sposób postrzegał ks. Wyszyński problematykę pracy, którą w czasach, gdy opracowywał swój skrypt, zaliczał do zagadnień polityki społecznej. Cytując ks. Antoniego Szymańskiego, postrzegał ją jako „naukę o stosunku między kapitałem i pracą albo o dobrobycie warstwy zarobkującej” [Wyszyński 2020, 28]. Jak wyjaśniał, „W polityce społecznej na czoło wysuwa się człowiek pracujący. Ma ona na uwadze dobro warstwy pracującej, obejmuje swym badaniem wszystkich ludzi pozostających w stosunku pracy najemnej, chociaż ze szczególną uwagą zajmuje się pracownikiem fizycznym. Uczy jak ułożyć należycie stosunek między pracodawcami a pracobiorcami, głównie robotnikami fizycznymi zarówno miejskimi jak i wiejskimi" [tamże]. To personalistyczne spojrzenie dotyczy przede wszystkim oceny różnorodnych instytucji gospodarczych, która w pierwszej kolejności jest „wybitnie osobowościowa”. Jak argumentował „Motywy moralne - godność człowieka, życie rodzinne, religijne, obowiązki obywatelskie wysyłane są jako motywy, wpływające na wysokość płacy, czas pracy, organizację techniczną pracy" [tamże, 29]. Objaśniając znacznie ustawodawstwa społecznego w kontekście katolickiej nauki społecznej, ks. Wyszyński chętnie nawiązywał do encykliki Quadragesimo anno Piusa XI i przypominał, że to właśnie katolicy byli promotorami ustawodawstwa społecznego. Dla Wyszyńskiego, kwestia społeczna to „zagadnienia naukowe 
i społeczne wynikające $\mathrm{z}$ dążenia do utrzymania równowagi społecznej i gospodarczej, zagrożonej wskutek niepomyślnego położenia warstw pracujących, niezgodnego z etyką chrześcijańską i równością społeczną" [tamże, 30]. „Zakres kwestii społecznej jako zagadnienia naukowego i praktycznego jest bardzo szeroki, wchodzi tu: strona ekonomiczna - zagadnienia dobrobytu materialnego warstw społecznych, strona społeczna - zagadnienie stanowiska społecznego i obywatelskiego warstw robotniczych, strona moralna - zagadnienia stanu moralnego i kulturalnego bytowania robotników. Z uwagi na złożone zagadnienia do rozwiązania kwestii społecznej powołane są wszystkie czynniki zainteresowane, a więc Kościół, państwo, korporacje zawodowe, robotnicy, rodzina, szkoła, organizacje społeczno-zawodowe, polityczne, ekonomiczne i społeczne. Typowym przykładem dla ustalenia zakresu nauki kwestii społecznej jest encyklika Rerum novarum" [tamże].

Ks. F. Mazurek podsumowując personalistyczno-integralne ujęcie katolickiej nauki społecznej w eksplikacji ks. Wyszyńskiego, wymienia kilka cech tej metody myślenia. Są nimi: personalizm, interdyscyplinarność, biblicyzm, oparcie na dynamicznie pojmowanym prawie naturalnym, historycyzm, etycyzm i praktycyzm [Fel 2020, 182-95]. Ks. Wyszyński, przywołując encykliki społeczne, „opowiada się za prawną ochroną praw społecznych” z wyeksponowaniem rangi osoby ludzkiej z jej naturalną i nadprzyrodzoną godnością, która stanowi fundament wrodzonych praw osoby ludzkiej [tamże, 182-83].

Myśl Wyszyńskiego na temat pracy jest owocem nie tylko intelektualnej refleksji nad osiągnięciami europejskich myślicieli katolickiej nauki społecznej, ale nade wszystko ma swoje zakorzenienie w osobistym doświadczeniu życia duchowego i formacji biblijnej. Dlatego też bardzo często nawiązuje on do zakodowanego na kartach Pisma Świętego obrazu i pochwały „pracy” Boga. Człowiek bowiem, „nic nie tworzy, tylko przetwarza gotowe dary Boże. Jedynie Bóg działa i tworzy we właściwym tego słowa znaczeniu: człowiek jest natomiast współpracownikiem Boga, Jego pomocnikiem” [Wyszyński 2001, 30]. Wyszyński ową rzeczywistość duchową pracy określa w oryginalny sposób jako „Boże prawo pracy”. Praca ma zatem wymiar transcendentny, to znaczy: przekracza porządek materialny, dociera do świata duszy, realizuje porządek Boży i wolę Bożą [Bartnik $2001,10]$. 
Praca według Wyszyńskiego ma też wymiar paschalny, to znaczy, praca podejmowana $\mathrm{z}$ miłości ku Bogu jest uczestnictwem $\mathrm{w}$ dziele odkupienia i zbawienia. „Praca dla miłości Boga jest uczestnictwem człowieka nie tylko w dziele stworzenia, ale i w dziele odkupienia naszego [...]. Chrześcijańska postawa wobec trudu pracy na tym polega, że tej męce, której nie da się usunąć nawet na drodze sprawiedliwego ustroju pracy, chcemy nadać charakter zbawczy".

Obok wymiaru duchowego i indywidualnego, Wyszyński podkreślał też jej wymiar wspólnotowy (środowisko pracy) i społeczny (dobro wspólne). Wyszyński przypominał, że „nie może być pracy bez zrozumienia jej użyteczności” [Wyszyński 1993, 343]. Przez pracę użyteczną rozumiał jako „nadanie jakiejś nowej wartości rzeczy, dziełu, do którego praca się odnosi” [tamże]. W tym aspekcie wyraźnie nawiązywał do encykliki Piusa XI Quadragesimo anno, który pisał o tworzeniu dóbr prawdziwie użytecznych. Zdaniem Wyszyńskiego, tak pojęta praca jest ważnym, ale nie jedynym celem trudów człowieka - „by w pełni być użyteczną, musi przydawać ważności nie tylko rzeczy, ale i samemu człowiekowi”.

Skoro zatem praca ma wymiar transcendentny, a więc przekracza porządek materialny, stanowi swoiste odbicie porządku Bożego, ma swój walor duchowy, gdyż podejmowana z miłości ku Bogu jest uczestnictwem w dziele odkupienia i zbawienia, toteż samo prawo pracy stanowi istotny rozdział upowszechniania się ducha chrześcijańskiej miłości bliźniego. Kardynał Stefan Wyszyński postrzegał prawo pracy nie tylko jako uporządkowany zbiór przepisów powszechnie obowiązujących i autonomicznych, lecz także jako potrzebę rozumnej natury człowieka zakorzenionej w sferze moralności chrześcijańskiej. Ustawodawstwu pracy nadawał niezwykle wysoką rangę, jak twierdził - „katolicy powinni widzieć w prawie pracy dalszy ciąg prawodawstwa, zapoczątkowanego ongiś przez Boga; powinni widzieć upowszechnienie się ducha chrześcijańskiej miłości bliźniego, postęp moralności społecznej i sprawiedliwości nakazanej przez Boga" - i dalej - „Odsuwamy w tej chwili na obok twórców prawa, partie polityczne. Idzie o samą sprawę, która wyszła z ducha na wskroś chrześcijańskiego, sumienia wychowanego przez wpływy Ewangelii. I to jest dla nas najbardziej istotne" [tamże, 398]. Pierwsze bowiem ustawy pracy mają swój początek w Dekalogu, a biblijne opisy ochrony człowieka pracującego zaczynają się już od momentu wysłania Mojżesza do Egiptu przez Boga, 
który widział „utrapienie ludu [...]” i słyszał „krzyk jego dla surowości tych, którzy są przełożeni nad robotnikami” (Wyj 3,7).

Według Wyszyńskiego, „dziś mamy szczególne obowiązki wobec prawa pracy:

1. nie zwalczać go w jego założeniach, lecz dążyć do ulepszenia i rozwoju $[\ldots]$

2. dążyć do pogłębienia jego sprawiedliwości poprzez wyzwalanie ustawodawstwa pracy spod przetargów politycznych. Należy wydobyć je z rąk polityków, a podnieść do rzędu wyższej moralności społecznej [...]

3. rozbudzać poszanowanie prawa pracy i piętnować zgwałcenie i naruszanie go. Ongiś samo społeczeństwo katolickie, wychowane przez Kościół, bez żadnych praw wypełniał obowiązki głoszone dziś przez kodeks pracy. Czyniły to szczególnie bractwa religijne, korporacje, stowarzyszenie zawodowe. Dziś zadania te muszą spełniać katolicy, którzy powinni przodować poczuciem sprawiedliwości i pokoju społecznego" [Wyszyński 1993, 399-400].

Szczególne obowiązki wobec prawa pracy mają katolicy. Ks. Wyszyński przypomina, że przestrzeganie ustawodawstwa pracy obowiązuje w sumieniu ,jako część prawa państwowego, jak każde rozumne prawo, wydane przez prawowitą władzę państwową" [tamże, 397]. Jeśli zatem regulacje prawa pracy są sprawiedliwe, tj. „zmierzają do dobra ogółu, jeśli nie przekraczają uprawnień władzy prawodawczej, a ciężary słuszne rozkłada wtedy w sumieniu obowiązuje” [tamże]. Jak obserwował - „zanik moralności w życiu gospodarczym upoważnioną aż nadto często do obchodzenia prawa pracy, do unikania tzw. «ciężarów społecznych», które uważano za niesprawiedliwie nałożone. Poprawić należy obyczaj, skłaniając do posłuszeństwa «nie tylko dla pomsty, ale i dla sumienia» (Rz. 23,5)" [tamże].

W okresie wojennym ksiądz Wyszyński podejmuje próbę wskazania zasadniczych kierunków rozwoju prawa pracy. Nawiązując do encyklik papieży realistycznie dostrzega, że „zakres prawa pracy prawdopodobnie będzie coraz szerszy, w miarę pogłębiania się moralności społecznej”. Jego zdaniem powinno ono „określać prawa i obowiązki wzajemne robotników i pracodawców, i wolność zrzeszania się, warunki umowy o pracę; otoczyć opieką prawa człowieka pracującego, jego zdrowie, siły, moralność, religijność; ochronić zarobki, ustrzec od nieszczęśliwych wypadków przy pracy, w duchu przykazania Bożego «nie zabijaj»” [tamże, 395]. Ponadto, „ustawy państwowe powinny mieć na celu poprawę warunków społecznych, losu robotnika, zabezpieczenie jego bytu i jego praw. Do pomocy specjalnych 
ustaw społecznych może się państwo odwoływać w następujących wypadkach: gdy trzeba osłonić osobistą własność robotnika; zawczasu usunąć przyczyny zatargów między przedsiębiorcami i robotnikami; ochronić robotników przed wyzyskiem pracy; określić czas dnia roboczego, przerwy pracy dziennej, warunki zdrowotności pracy, wypoczynku itd.; by otoczyć opieką dobra duchowe robotników, dni świąteczne, możność spełniania obowiązków religijnych i publicznej czci Boga; osłonić powagą ustaw pracę dzieci i kobiet itd.” [tamże]

\section{ZAKOŃCZENIE}

Myśl kard. Stefana Wyszyńskiego na temat pracy to oryginalna synteza społecznego nauczania Kościoła, inspirowana dwoma encyklikami - Rerum novarum i Quadragesimo anno oraz mistagogicznych katechez, które ukazują wartość indywidualnej i wspólnotowej pracy jako żywe uczestnictwo w misteriach Chrystusa. Trudno jest wskazać ludzi, którzy w pełni ukształtowali myśl Prymasa na temat pracy. Był bardzo samodzielny. Różne elementy czerpał od różnych osób, ale jednocześnie nadawał temu specyficzny, własny rys. Od samego początku zajmował samodzielne stanowisko, jednocześnie silnie korzystając np. z dorobku KUL-owskich profesorów, m.in. ks. Szymańskiego. Stawiał sobie wysokie wymagania. Kiedy zdecydował się na kapłaństwo, wybrał nie diecezjalne seminarium w Płocku, o średnim poziomie, lecz ambitniej - seminarium we Włocławku. A było to wówczas intelektualne i duchowe centrum Kościoła w Polsce. Cechował je ferment intelektualny, ale zarazem wierność ortodoksji. W tym środowisku wzrastały tak ważne postacie dla Katolickiego Uniwersytetu Lubelskiego, jak ksiądz Idzi Radziszewski rektor seminarium i późniejszy pierwszy rektor KUL, ks. M.L. Fulman który w listopadzie 1918 r. został biskupem lubelskim, czy też wykładowca filozofii i nauk społecznych w seminarium duchownym we Włocławku ks. prof. A. Szymański. Kard. Wyszyński bardzo cenił kard. Desiré Merciera, jednego z najwybitniejszych tomistów, przewodniczącego Unii Mechlińskiej. Unia Mechlińska, której nazwa wzięta została od siedziby prymasów w Belgii w Malines, to bardzo znaczący instytut badawczy który inspirowany encykliką Rerum novarum rozpoczął badania naukowe nad filozofią tomistyczną, podejmującą próby kodyfikacji tez katolickiej nauki społecznej. Warto odnotować, że przed 
wojną członkami unii byli dwaj Polacy: ks. A. Szymański i Ludwik Górski (ekonomista, działacz katolicki, profesor KUL). Ponadto, od pierwszego roku studiów (mimo, że praca doktorska ks. Prymasa dotyczyła prawa kanonicznego) uczestniczył w wykładach ks. prof. A. Szymańskiego na temat kapitalizmu i kolektywizacji, ustawodawstwa pracy, ubezpieczeń społecznych, teorii polityki społecznej i socjologii, a od czwartego roku studiów brał udział w kierowanym przez niego seminarium $\mathrm{z}$ zakresu polityki społecznej.

Praca dla kardynała Stefana Wyszyńskiego miała przede wszystkim wymiar duchowy. W książce „Duch pracy ludzkiej” wskazywał on na nierozerwalny związek pomiędzy tym co rozumiemy jako „praca zewnętrzna”, czyli wszelkie wytwory pracy człowieka i tym co rozumiemy jako „pracę wewnętrzną" rozumianą jako rodzaj zmagania duchowego w pracy. Według ks. Wyszyńskiego rozumna, szlachetna, celowa, użyteczna praca, która jest podejmowana z miłości ku Bogu, to „najszlachetniejsza forma uwielbienia Boga" [Wyszyński 2001, 68-69]. Ma ku temu prowadzić podniesienie $\mathrm{w}$ procesie pracy, myśli, woli serca ku Bogu. Według Wyszyńskiego praca ludzka jest współpracą z Bogiem, jeśli jej zewnętrzny i wewnętrzny wymiar prowadzi do uświęcenia. Szczególnie potrzebna jest „nadprzyrodzona organizacja pracy, w której trud pracy ma swoją modlitwę. Skupienie modlitewne w pracy to zwracać ku Bogu przedmiot naszej pracy" [tamże, 75]. Towarzyszyć temu ma ascetyka pracy, czyli z jednej strony wdzięczność za zaszczyt powołania do współpracy z Bogiem, a z drugiej strony ofiara oddania się Bogu a nie ludziom. Zdaniem Wyszyńskiego modlitwa w pracy to konieczność i radość. Jest to wewnętrzne poddanie się Bogu, podporządkowanie swoich myśli, uczuć, sił i woli ludzkiej rozkazom woli Bożej - stworzyć własny świat modlitwy w pracy. Dlatego też „nie należy przesadzać w określeniu nasza praca”, raczej poprzez pracę dążyć do zadośćuczynienia Bogu - ofiarowanie trudów i owoców pracy. Przez pracę człowiek uczestniczy w dziele stworzenia i współdziała ze Stwórcą; jest też wartością eschatologiczną - pracujący uczestniczy w dziele odkupienia, gdyż praca zawiera coś z krzyża, ze składaniem Bogu ofiary.

$\mathrm{Z}$ dzisiejszej perspektywy dostrzegamy, jak bardzo ascetyka pracy codziennej, o której mówił i pisał kardynał Stefan Wyszyński, zachowuje swój walor aktualności. W czasach, kiedy tak wielu ludzi poszukuje mentorów, coachów, przewodników, gdzie tyrania pracy prowadzi do wypalenia zawodowego, negatywnych skutków społecznych i rodzinnych, ks. 
Wyszyński przypomina, że każde działanie ma swój proces wewnętrzny, a punktem wyjścia każdej pracy ma być życie wewnętrzne [tamże, 95].

Współczesny wymiar pracy w coraz większym stopniu zdeterminowany jest przez nowe technologie. Portale społecznościowe, komunikacja elektroniczna umożliwia pracodawcy praktycznie 24-godzinny kontakt ze swoim pracownikiem. W prawie pracy od kilku lat funkcjonuje pojęcie „prawo do odłączenia” - czyli nakaz nałożony na pracodawcę niekomunikowania się ze swoim pracownikiem poza godzinami pracy. Kard. Wyszyński przypominał, że nie każdy ustrój techniczny jest godziwy i dobry tylko dlatego, że podnosi wydajność fabryki. Jak pisze dalej „fabryka nie jest bogiem, ale jej życie i praca mają służyć Bogu" [Wyszyński 1993, 369-79].

Kardynał Wyszyński wychodząc z perspektywy biblijnej podejmuje także problem odpoczynku, zwłaszcza wypoczynku świątecznego. Jak podkreśla, oprócz religijnego charakteru odpoczynek od pracy wymaga dodatkowych warunków: powinien być powszechny i społeczny. „Społeczny charakter wypoczynku niweczy nadmierna ilość wyjątków od ustawy o czasie pracy; sprawia ona to, że zbyt wielka ilość ludzi nie odczuwa różnicy między dniem powszednim a świątecznym, a wraz z nimi i ci, którzy są świadkami i w pracy”, i dalej, „doświadczenie bolszewików, którzy powodowani nienawiścią do chrześcijaństwa wprowadzili tak zwaną "nieprzerywkę»" [tamże, 391], potwierdza, jak wielkie szkody społeczne przynosi tutaj walka z tymi urządzeniami Bożymi. Czyż ten rodzaj „nieprzerywki” nie dotyczy rzeszy pracowników zatrudnionych w sklepach wielkopowierzchniowych, marketach. W debacie na temat zakazu handlu w niedzielę dużo miejsca poświęca się dyskomfortowi konsumentów - kupujących, podawane są przeróżne dane statystyczne. Dość często w tej perspektywie zapomniany o idei solidarności, a co za tym idzie pewnego rodzaju umiejętnością społecznego poświęcenia przez innych, dotkniętych ową „nieprzerywką”. W Polsce regulacja zakazu handlu $\mathrm{w}$ niedzielę jest ważnym osiągnięciem społecznym i socjalnym. Przypomnijmy, że zakaz handlu w niedzielę wszedł w pełni od początku 2020.

Jeśli chodzi o samo ustawodawstwo pracy, to zdaniem Wyszyńskiego „katolicy powinni widzieć w prawie pracy dalszy ciąg prawodawstwa zapoczątkowanego ongiś przez Boga; powinni widzieć upowszechnienie się ducha chrześcijańskiej miłości bliźniego, postęp moralności społecznej i sprawiedliwości nakazanej przez Boga”. „Odsuwamy w tej chwili na bok twórców prawa, partie polityczne. Idzie o samą sprawę, która wyszła z ducha 
na wskroś chrześcijańskiego, sumienia wychowanego przez wpływy Ewangelii. I to jest dla nas najbardziej istotne. Prawo pracy - to wielki rozdział moralności chrześcijańskiej” [tamże, 394]. Wyzwanie Wyszyńskiego do przestrzegania i rozwoju ustawodawstwa pracy z dzisiejszej perspektywy należy postrzegać $\mathrm{w}$ duchu personalistycznym. Nowoczesne prawo pracy wyzwolone z przetargów politycznych, oparte na personalistycznej wizji pracy, to ustawodawstwo, które niekoniecznie opiera się wyłącznie na przepisach powszechnie obowiązujących. Pamiętajmy, że ustawodawstwo pracy to także tak zwane autonomiczne czy też, jak inni nazywają, specyficzne źródła prawa. Należą do nich przede wszystkim układy zbiorowe pracy, porozumienia zbiorowe, czyli tak jak określał swego czasu Wyszyński ustawodawstwo fabryczne będące przedmiotem rokowań zbiorowych.

$\mathrm{W}$ tym zakresie polskie prawo pracy ma wiele do zrobienia. Zbyt mocno oparte jest jeszcze na doświadczeniach państw socjalistycznych i jednostronnej metodzie kształtowania prawa, w której szczególną rolę ma odgrywać ustawa i rozporządzenie. Dość powiedzieć, że ta metoda kształtowania prawa pracy, w której dominującą rolę odgrywa rozbudowane ustawodawstwo, nie jest powszechnie stosowana na świecie. Personalistyczna wizja pracy zakłada upodmiotowienie strony pracowniczej poprzez tworzenie przestrzeni negocjacyjnej dla związków zawodowych i pracodawcy. Dobrą drogą dla rozwoju prawa pracy jest poszukiwanie równowagi w zakresie kształtowania praw i obowiązków pracodawcy i pracownika, a najlepszą metodą osiągania tej równowagi są układy zbiorowe pracy. Mogą mieć one charakter zakładowy, czyli obowiązywać u danego przedsiębiorcy, mogą też mieć charakter branżowy myśli ponadzakładowy. Istotnymi elementami rokowań zbiorowych, bez których trudno wyobrazić sobie całą procedurę kształtowania prawa pracy, z silnym oparciem na regułach aksjologicznych, są: dbałość o dobro zakładu pracy, niewysuwanie żądań ponad miarę, dążenie do zachowania pokoju społecznego i tym podobne. Odrębną troską i refleksją należy otoczyć sam ruch związkowy, który w ostatnich latach w Polsce, w Europie i na świecie przeżywa kryzys. Młodzi ludzie nie chcą należeć do związków zawodowych, nie rozumieją idei funkcjonowania ruchu związkowego, problematyka ochrony pracy w ich rozumieniu przyjmuje głównie postać ściśle zindywidualizowaną. Bez ruchu związkowego trudno mówić o równowadze między kapitałem a pracą. Rzecz dotyczy także środowiska pracy, a zwłaszcza współpracy człowieka z maszyną, z dzisiejszej perspektywy, moglibyśmy powiedzieć, nowoczesną 
technologią, automatyzacją, sztuczną inteligencją i zarządzaniem algorytmicznym. Jak wyjaśniał kard. Wyszyński, „człowieka wchodzącego do fabryki nie można stawiać w jednym rzędzie z maszyną czy narzędziem; nie można żądać by upadł czy oddał im pokłon i samej maszynie służył. Maszyna [dzisiaj czytaj robotyka, technologia, SI - P.N.] nie jest bogiem". Rozwój nowych modeli biznesowych wykorzystujących narzędzia cyfrowe zwiększa zapotrzebowanie na pracę projektową, dorywczą lub wykonywaną „na żądanie”, której coraz częściej nie towarzyszą standardowe gwarancje socjalne. Jedną z przyczyn jest pojawienie się platform tzw. ekonomii współdzielenia, takich jak np. Uber, coraz skuteczniej konkurujących z tradycyjnym sektorem usług. Cyfryzacja gospodarki ma jednak również inne oblicze. Szybki rozwój technologii związanych z robotyzacją i badaniami nad sztuczną inteligencją sprawia, że w coraz większym zakresie ludzi zastępują w pracy maszyny i programy komputerowe. Jeszcze kilka lat temu automatyzacja kojarzyła się wyłącznie z usprawnieniem procesów produkcyjnych, np. w fabrykach samochodów. Dziś algorytmy pod postacią programów komputerowych zaczynają stanowić konkurencję również dla pracowników umysłowych i przedstawicieli wolnych zawodów. Badania inspirowane ideą „drugiej ery maszyn” wskazują na wysoki potencjał automatyzacji rynków pracy krajów członkowskich Unii Europejskiej. Według nich aż 54\% unijnego rynku pracy jest zagrożone automatyzacją w ciągu najbliższych dwóch dekad. Polska znajduje się w grupie krajów najbardziej podatnych na automatyzację rynku pracy. Związane jest to $\mathrm{z}$ dużą ilością miejsc pracy w sektorze maszynowym i motoryzacyjnym wymagających rutynowych czynności, które łatwo zastąpić przez maszyny (tj. montaż podzespołów). Okazuje się, że myśl kard. Wyszyńskiego dotycząca relacji człowiek-maszyna, odczytywana z dzisiejszej perspektywy, jeśli chodzi o najważniejsze idee i zasady, nadal zachowuje walor aktualności. Jak pisał: „Do zwykłego trudu, który właściwy jest wszelkiej pracy, a zwłaszcza fabrycznej, dołącza się trud dodatkowy, wywołany samą techniką organizacyjną: nowa organizacja pracy dąży do tego, by najstaranniej wykorzystać czas, siły robotnika, by podnieść jego biegłość i sprawność" współcześnie jest to problem zarządzania algorytmicznego, nadzorowanego przez rodzaj sztucznej inteligencji. Celem prawa pracy nie może być odhumanizowanie środowiska pracy. Prawo pracy nie może zrezygnować z relacji osobowych w środowisku pracy. Sztuczna inteligencja nie może pełnić roli pracodawcy, nie może mieć podmiotowości prawnej. 
W czasie, kiedy powstawały teksty Wyszyńskiego na temat pracy piętnował on przede wszystkim dehumanizację wynikającą $\mathrm{z}$ mechanizacji, racjonalizacji, tayloryzacji pracy „dzisiejsza technika pracy fabrycznej poniża człowieka, odziera go z godności ludzkiej z radości Bożych” [Wyszyński 1993, 369] - z dzisiejszej perspektywy możemy zastanawiać się, czy słowa Wyszyńskiego straciły na aktualności, czy też należy do nich wracać w kontekście zmian cywilizacyjnych i technologicznych. Dawniej i obecnie należy pamiętać, że praca zachowuje swój głęboki wymiar duchowy, że instytucje prawa pracy wymagają głębokiej refleksji nad realizacją wizji personalistycznej więzi pracy, a nowe technologie nie mogą stać się kolejną wersją uprzedmiotowienia, utowarowienia pracy.

\section{PIŚMIENNICTWO}

Bartnik, Czesław. 2001. „Wstęp.” W Stefan Wyszyński, Duch pracy ludzkiej, 5-12. Warszawa: Wydawnicto im. Stefana Kard. Wyszyńskiego Sole Deo. Instytut Wydawniczy Pax.

Bender, Ryszard. 1981a. „Chrześcijańska myśl i działalność społeczna w okresie międzypowstanowym 1832-1918." W Czesław Strzeszewski, Ryszard Bender, i Konstanty Turowski, Historia katolicyzmu społecznego w Polsce 1932-1939, 23-62. Warszawa: Ośrodek Dokumentacji i Studiów Społecznych.

Bender, Ryszard. 1981b. „Chrześcijańska myśl i działalność społeczna w zaborze rosyjskim w latach 1865-1918.” W Czesław Strzeszewski, Ryszard Bender, i Konstanty Turowski, Historia katolicyzmu społecznego w Polsce, 201-56. Warszawa: Ośrodek Dokumentacji i Studiów Społecznych.

Fel, Stanisław. 2020. „Stefan Wyszyński - prekursor lubelskiej szkoły katolickiej nauki społecznej.” W Stefan Wyszyński, Chrześcijańska doktryna społeczna, 1-201. Lublin: Wydawnictwo KUL.

Fortuniak, Zbigniew. 1971. „Chrześcijańska koncepcja pracy w nauczaniu księdza kardynała Stefana Wyszyńskiwgo.” W Bohdan Bajzy, W kierunku człowieka, 85-103. Warszawa: Akademia Teologii Katolickiej.

Jarocki, Stanisław. 1964. Katolicka nauka społeczna. Paris: Societe D’Editions Internationales.

Jaroszyński, Edward. 1908. Katolicyzm Socyalny. Warszawa: Księgarnia Narodowa M. Szczepkowskiego.

Leszczyński, Adam. 2020. Ludowa historia Polski. Warszawa: W.A.B.

Matulewicz, Jerzy. 1907. „Chrześcijańska teoria prawa własności. Kursa społeczne”. Biblioteka Dziet Chrześcijańskich, wrzesień-październik, 1-93.

Nitecki, Piotr. 2006. Ksiadz Stefan Wyszyński. Student KUL w latach 1925-1929. Lublin: Katolicki Uniwersytet Lubelski. 
Nitecki, Piotr. 2007. „Ksiądz Stefan Wyszyński jako profesor katolickiej nauki społecznej we Włocławku (1931-1939).” Studia Prymasowskie 1:215-39.

Pawlak, Zdzisław. 2011. „Włocławski okres działalności naukowej ks. prof. Antoniego Szymańskiego.” Studia Włocławskie, t. 13, 209-23.

Peciakowski, Tomasz. 2018. „Ks. Antoni Szymański (1881-1942).” https://www.kul.pl/ ks-antoni-szyma-ski-1881-1942,art_79442.html [dostęp: 03.02.2021].

Raina, Peter. 2006. Kardynat Wyszyński. Tom 1. Droga na Stolicę Prymasowska. Warszawa: Wydawnictwo Von Borowiecky.

Sitarz, Mirosław. 2017. „Lata studenckie Księdza Stefana Wyszyńskiego w Lublinie.” Biuletyn Stowarzyszenia Absolwentów i Przyjaciót Wydziału Prawa Katolickiego Uniwersytetu Lubelskiego 14 (1):81-101.

Strzeszewski, Czesław, i Marian Banaszek. 1981. „Chrześcijańska myśl i działalność społeczna w zaborze pruskim w latach 1865-1918.” W Czesław Strzeszewski, Ryszard Bender, i Konstanty Turowski, Historia katolicyzmu społecznego $w$ Polsce 1832-1939, 63-134. Warszawa: Ośrodek Dokumentacji i Studiów Społecznych.

Strzeszewski, Czesław. 2012. „Chrześcijańska doktryna społeczna. Stenogram z wykładów prof. Czesława Strzeszewskiego.” Roczniki Nauk Społecznych 4 (40), nr 1:118-46.

Szymański, Antoni. 1913a. Studya i Szkice Społeczne. Warszawa: Bilioteka Dzieł Chrześcijańskich.

Szymański, Antoni. 1913b. Uświadomienie katolickie: przeglad krytyczny literatury religijno-katolickiej polskiej. Warszawa: Bilioteka „Prądu”.

Szymański, Antoni. 1916. Zagadnienie społeczne. Włocławek: Nakładem Księgarni Powszechnej.

Szymański, Antoni. 1925. Polityka Społeczna. Lublin: Uniwersytet Lubelski.

Szymański, Antoni. 1939. Zagadnienia społeczne. Wydanie III przerobione. Lublin: Towarzystwo Wiedzy Chrześcijańskiej.

Woroniecki, Adam. 1906. Historja Katolickiej akcji społecznej w XIX. Szkic historyczno-spoteczny. Lublin: „Polak-Katolik”.

Wyszyński, Stefan. 1990. Nauczanie społeczne 1946-1981. Warszawa: Ośrodek Dokumentacji i Studiów Społecznych.

Wyszyński, Stefan. 1993. Miłość i Sprawiedliwość Społeczna. Rozważania społeczne. Poznań: Pallottinum.

Wyszyński, Stefan. 2001. Duch pracy ludzkiej. Myśli o wartości pracy. Warszawa: Instytut Wydawniczy Pax.

Wyszyński, Stefan. 2020. Chrześcijańska doktryna społeczna. Lublin: Wydawnictwo KUL.

Zimmermann, Kazimierz. 1908. „Znaczenie stanu robotniczego dla społeczeństwa i Kościoła.” Ruch Chrześcijańsko-Społeczny, 1-69. 


\section{Formacja intelektualna ks. Stefana Wyszyńskiego w dziedzinie pracy ludzkiej i ustawodawstwa pracy - okresy II RP i II wojny światowej}

\section{Streszczenie}

Myśl Wyszyńskiego na temat pracy jest owocem nie tylko intelektualnej refleksji nad osiągnięciami europejskich myślicieli katolickiej nauki społecznej, ale nade wszystko ma swoje zakorzenienie w osobistym doświadczeniu życia duchowego i formacji biblijnej. Celem artykułu jest próba odpowiedzi na pytanie, w jaki sposób kształtowała się formacja intelektualna w zakresie problematyki pracy i ustawodawstwa pracy w świetle katolickiej nauki społecznej. Celem artykułu jest także poszukiwanie odpowiedzi na pytania pomocnicze: jakiego rodzaju aktywność społeczną podejmował w odniesieniu do realizacji myśli społecznego nauczania Kościoła? Czym jest praca i jakie cele stoją przed ustawodawstwem pracy według ks. Wyszyńskiego? Co myśl ks. Wyszyńskiego na temat ustawodawstwa pracy może wnieść do współczesnej doktryny prawa pracy?

Słowa kluczowe: praca człowieka; ustawodawstwo pracy; katolicka nauka społeczna; ks. Wyszyński

\section{Intellectual Formation of Fr. Stefan Wyszyński in the Field of Human Labor and Labor Legislation - Periods of the Second Republic and Second World War}

\section{Summary}

Wyszyński's thought on work is the result not only of intellectual reflection on the achievements of European thinkers of Catholic social teaching but, above all, it is rooted in his personal experience of spiritual life and biblical formation. This article aims to attempt to answer how intellectual formation in the field of labour issues and labour legislation was shaped in the light of Catholic social teaching. The purpose of the article is also to seek answers to the following questions: what kind of social activity was undertaken concerning implementing the thought of the social teaching of the Church? What is work, and what are the aims of work legislation according to Fr. Wyszyński? What can Fr Wyszyński's thought on labour legislation contribute to the contemporary doctrine of labour law?

Keywords: human labour; work legislation; catholic social science; Fr. Wyszyński

Information about Author: DR. HABIL. PAWE€ NOWIK - Department of Labour and Social Insurance Law, Faculty of Law, Canon Law and Administration, the John Paul II Catholic University of Lublin; correspondence address: Al. Racławickie 14, 20-950 Lublin, Poland; e-mail: pawelnowik@kul.pl; https://orcid.org/0000-00021824-0884 